parteiensystem handelt, hätten die Parlamentswahlen berücksichtigt werden sollen, da auch andere politische Parteien regelmäßig Mandate gewonnen haben.

Die philippinischen Parlamentswahlen (1987) nach dem Sturz von Ferdinand Marcos brachten "a significant majority for the pro-Aquino parties" (S. 275). Nähere Angaben sucht der Leser vergeblich.

Ein weiteres Manko dieses Handbuches besteht darin, daß es für komparative Studien wegen der unterschiedlichen Darstellungsweise (nur Sitzverteilung oder nur Prozentangaben) kaum zu nutzen ist. Angaben zur Wahlbeteiligung finden sich - wenn überhaupt - im Text versteckt.

Wer einen schnellen und guten Überblick über Wahlen in einem beliebigen Land sucht und sich dabei nicht auf die westlichen Demokratien beschränken will, wird enttäuscht. Trotz aller Kritik muß festgestellt werden, daß für ein Wahlhandbuch wie dieses Bedarf besteht. Die verbesserungsfähigen Punkte könnten in einer neuen, aktualisierten Auflage ohne große Mühen korrigiert und ergänzt werden.

Heiko Meinhardt

Carsten Herrmann-Pillath

Institutioneller Wandel, Macht und Inflation in China. Ordnungstheoretische Analysen zur Politischen Ökonomie eines Transformationsprozesses

Schriftenreihe des Bundesinstituts für ostwissenschaftliche und internationale Studien, Band 21

Nomos Verlagsgesellschaft, Baden-Baden, 1991, 734 Seiten, DM 80,--

The People's Republic of China (PRC), the world's most populous state, a permanent member of the United Nations Security Council and a nuclear power has, since the demise of Mao Tse-tung and his "Gang of Four", vigorously sought to re-enter international politics and commerce in a renewed bid to achieve domestic prosperity and to restore the Chinese nations's (Chung-hua min-tsu) global standing which had so painfully suffered during the past 150 years. Having re-emerged as a significant actor on the international stage, the Peking government has gone to considerable lengths to claim, eg. reintegration into frameworks of international trade, such as the General Agreement on Tariffs and Trade (GATT) or the future World Trade Organisation (WTO), but has met with a cautious response from some who remain apprehensive of certain specificities of the Chinese bodies politics and economic seen as a possible liability in PRC in participation in arrangements requiring effective domestic implementation of international 
commitments. This apprehension regards, in some ways similar to the case of Japan ${ }^{1}$, a perceived inability or perhaps even reluctance of the central government to exercise its authority so as to enforce national policy against powerful regional interests.

Professor Herrmann-Pillath's extensive study sets out to cast light on one fundamental aspect of government authority in the PRC during the decade of economic reforms from 1979 to 1989, namely the occurrence, perception of and political as well as popular reaction to inflation. Inflation as an economic and political phenomenon serves as an analytical vantage point from which the material constitution of the PRC polity and the characteristic difficulties of the Chinese modernising process are described.

The book comprises three parts, on the theoretical foundations of the enquiry, on money supply and the monetary order in the PRC and, finally, investigation of inflation in the PRC as an element of social change in a modernising state.

In the first part can be found a helpful overview of PRC scholars' debates of economic reform strategy and also of the ideological vicissitudes of academic participation in the formulation of government policy. The domination theme of such debate, replicating largely the Western market/plan dichotomy, was, then as now, the choice of whether the Chinese economy, poised in a no man's land between a 'market' and a 'planned' economy and condemned to institutional change on pain of failure, should plunge forward or test the water step by step (mo-che shih-t'ou kuo hsi - cross the brook by feeling your way [forward] from one stone to the next, in the pithy dictum of Teng Hsiao-p'ing). Inflation lurked all along the way as socio-economic detonator which had already blown the Republican régime of Chiang Kai-shek to smithereens forty years earlier.

Much to the chagrin of economists and politicians alike, 'inflation' is a "many-splendoured thing" and its effects as potentially multifarious as the guises in which it appears to statisticians, entrepreneurs, bankers of consumers, in the towns and cities or in the countryside. The second part of the book, dealing mainly with the organisation of the PRC banking sector and the processes of money creation, takes a closer look at quantitative aspects of inflation. Problems of data collection, temporal and spatial comparability as well as government-inspired manipulation of figures apart, the political virulence of inflation lies to a large extent in its perception by economic actors. In this regard the urban populations in the PRC are a particularly sensitive lot, more so perhaps than those viewing inflation in the country as a whole or from the countryside. Daily necessities, most importantly food, still taking up the lion's share of urban incomes, price rises for staple foods will quickly feed urban discontent. As the centres of modern industrial production and home of all institutions of higher education, China's cities have also been the repository of potential dissent and disobedience, from the May-Fourth Movement in

1 cf. Karl van Wolferen, The Enigma of Japanese Power. People and Politics in a Stateless Nation, London 1989. 
1919 to the almost exclusively urban unrest which ended with the massacre in T'ien-anmen Square on June 4th, 1989. Inflation thus looms much larger in the minds of the man on the Shanghai omnibus and the Peking autocrat than in the eye of the statistical observer.

Recurrent attempts in the PRC to grapple with inflation have been hampered by the inability of the central government to formulate and enforce a monetary policy vis-à-vis banks and enterprises which would set effective limits to money creation through credit granted not on the strength of economic viability buth with the purpose to subsidise investment and consumption for political ends. Two main sources of such inability emerge from the third part of the book - the fragmentation of PRC policy-making into a system of "multiple principals" and the difficulty to disentangle the entrepreneurial and welfare tasks until now incumbent on state-owned enterprises of the PRC, in order to create or increase factor mobility in the economy as a whole.

In the interaction of central authority and regional interests the "opening policies" of the decade under consideration have again strongly favoured the latter, diminishing the centre's power of taxation while relinquishing such power to a large degree to the regions, thereby paradoxically aggravating the tax burden on firms and households while starving central government of revenue needed not least for politically motivated subsidies. The foundations of this "involutionary" process are well described but less convincingly explained in the book.

The striking difference between rigid centralised hierarchy in the former Soviet Union and the bargaining in the PRC between regional powerholders and the centre is rightly emphasised but the specific Chinese dispensation then merely ascribed to cultural specificities (the informal system of "kuan-hsi", a nexus of mutual beholdingness somewhat similar to the English old-boy network, or effects of childhood socialisation) which are not further elucidated. The personal identity in the PRC of those representing the central nomenklatura as well as the regional interest at, eg. enterprise level may well be a building-block of the PRC's pluripolar system but a resulting weakness of the centre would not appear to be an ingrained feature of traditional government where powerful former dynasties, particularly in their initial periods, have been well able to bring regional interests to heel. The existence of modern communications as a possible aid to centralised control would suggest the need for further enquiry into what put puripolarity in place and maintains its strength. The traditional PRC state enterprise whose employés depend on the firm for their housing, kindergartens and medical care as much as for their salaries seems a more powerful factor in the PRC's "feudal economy" (chu-hou chingchi) than child psychology. This very own turf of latter-day feudatories in the PRC economy may, however, well be threatened by the necessary efforts at reseparating the entrepreneurial and wider welfare functions of economic undertakings. In the meantime one easily agrees with Professor Herrmann-Pillath's conclusion that the constitutional stalemate between the centre in Peking and its regional interlocutors in the attempt to make the central government's economic policy writ run through all of mainland China 
represents an unfinished task in modern state-building in the PRC. Until this conflict is resolved the perspiration provoked by multipolar tug-of-war will continue to trickle down on to the populace in the form of inflationary bouts, investive wast and general policy drift. It will leave the PRC as an increasingly important but inherently difficult partner on the international scene.

Professor Herrmann-Pillath's monograph deserves a wide readership among students of modern China; the author's extensive command of Chinese primary sources and the impressive breadth of economic scholarship have produced an analysis of the contemporary PRC economy which has no rival in the German-language literature of the field. A reviewer's quibble at the end: less convoluted language in many chapters would have made this important work much more accessible book.

Wolfgang Keßler

\section{Friedrich Oschmann}

\section{Calvo-Doktrin und Calvo-Klauseln}

Abhandlungen zum Recht der Internationalen Wirtschaft, Band 30

Verlag Recht und Wirtschaft, Heidelberg, 1993, 453 S., DM 198,--

In der hier anzuzeigenden umfangreichen Dissertation (381 S., einschl. Einleitung und zusätzl. Anhang) untersucht der Verf. die sog. Calvo-Doktrin - den Grundsatz der Inländerbehandlung des ausländischen Investors und den drohenden Verlust seiner Rechtsschutzmöglichkeiten, falls er in einem Streitfall mit dem Gastland sein Herkunftsland um diplomatischen Schutz anruft - und die daraus erwachsenden Klauseln im geltenden lateinamerikanischen Recht und der Rechtspraxis. Die Doktrin selbst geht zurück auf den argentinischen Juristen und Diplomaten Carlos Calvo und seine Ausführungen im Lehrbuch zum Internationalen Recht ("Le droit international théorique et practique", 5. Aufl. 1896, Vol. 6, S. 231); sie hat Eingang in eine Reihe von internationalen Regelungswerken gefunden, so u.a. in die Montevideo-Konvention von 1933 (Art. 9). Ihre eigentliche Funktion wurde bislang gesehen als traditioneller lateinamerikanischer Ansatz zur Abwehr des Mißbrauchs von diplomatischem Schutz und einer Relativierung des Fremdenrechts, nicht als Grundsatz der absoluten Gleichbehandlung um jeden Preis (vgl. García-Amador, Encyclopedia of Public International Law, Vol. 8, 1985, S. 62 ff.). Die Doktrin hat aber auch und vor allem im Rechtsverkehr mit und in den Staaten Lateinamerikas Bedeutung erlangt.

Oschmann sondiert völkerrechtlich und international-privatrechtlich. Im völkerrechtlichen Teil verortet er die Calvo-Doktrin im Prinzip der Gleichheit der Staaten (das "rechtsethische Prinzip, das seiner Doktrin zugrundeliegt", S. 27) und fragt danach, wann 